\title{
GAMBARAN KLINIS PENDERITA KANKER SERVIKS SETELAH KEMOTERAPI BERDASARKAN STADIUM
}

\author{
${ }^{1}$ Suwendar, ${ }^{2}$ Achmad Fudholi, ${ }^{3}$ Tri Murti Andayani, ${ }^{4}$ Herri S. Sastramihardja \\ ${ }^{1}$ Program Studi Farmasi Fakultas MIPA Universitas Islam Bandung \\ ${ }^{2,3}$ Fakultas Farmasi, Universitas Gadjah Mada, Yogyakarta \\ ${ }^{4}$ Fakultas Kedokteran, Universitas Padjadjaran, Bandung \\ email : suwendarsuwendar48@gmail.com
}

\begin{abstract}
ABSTRAK
Pendahuluan: Pengamatan gambaran klinik pada pada penderita kanker serviks merupakan hal yang sangat penting karena dapat mengevaluasi efektivitas kemoterapi. Tujuan: Tujuan penelitian ini adalah untuk mengetahui gambaran klinik pada penderita kanker serviks berdasarkan stadium setelah mendapatkan kemoterapi selama tiga siklus sehingga dapat dievaluasi lebih lanjut mengenai efektivitas kemoterapi untuk setiap stadium. Metode Penelitian: Penelitian ini merupakan jenis penelitian non eksperimental yang bersifat deskriptif dengan melakukan observasi lapangan untuk memperoleh data gambaran klinik. Evaluasi gambaran klinik dilakukan dengan mengamati gejala klinik dan kondisi pasca kemoterapi setelah pasien mendapatkan kemoterapi siklus pertama sampai ketiga. Kesimpulan Hasil: Hasil menunjukkan bahwa kemoterapi cenderung makin efektif pada pasien kanker serviks dengan stadium yang makin rendah. Setelah kemoterapi selama tiga siklus, pada gejala klinik, persen hilang gejala pada pasien stadium I, II, III dan IV untuk keputihan masing-masing adalah 100\%, 96\%, 93,3\% dan 25\%; pada gejala pendarahan, masing-masing adalah $100 \%, 68 \%, 53,3 \%$ dan $0 \%$; dan rata-rata skor nyeri masing-masing adalah $0,9 \pm 0,9 ; 1,0 \pm 1,5 ; 1,4 \pm, 4$ dan $3,5 \pm 1,9$. Penurunan skor nyeri yang bermakna terjadi pada pasien stadium I, II dan III masing-masing dengan nilai $\mathrm{p}=0,000$. Pada pasien stadium IV, penurunan skor nyeri tidak bermakna $(\mathrm{p}=0,391)$. Pada kondisi pasca kemoterapi, persentase pasien yang dinyatakan mengalami perbaikan pada stadium I, II, III dan IV masing-masing adalah $100 \%, 96 \%, 93,9 \%$ dan $75 \%$.
\end{abstract}

Kata Kunci: Kanker serviks, stadium, kemoterapi, gambaran klinik

\begin{abstract}
Background: Observation of clinical description on cervical cancer patients is very important because it can evaluate the effectiveness of chemotherapy. Aims: The objective of this research was to know the clinical description in cervical cancer patients based on stage after getting chemotherapy for three cycles so that the effectiveness of chemotherapy based on stage could be evaluated. Methods: This research was a non experimental descriptive using field observation to obtain clinical description data. Evaluation of clinical description was done by observe clinical symptoms and post-chemotherapy conditions after the patient got first to third chemotherapy cycles. Results and Conclusion: The results showed that chemotherapy was more effective in patients with lower stages. After chemotherapy for three cycles, on clinical symptoms, the percent loss of symptoms in patients with stage I, II, III and IV for whiteness were 100\%, 96\%, $93.3 \%$ and 25\%, bleeding symptoms were $100 \%, 68 \%, 53.3 \%$ and $0 \%$; and the mean of pain score were $0.9 \pm 0.9 ; 1.0$ $\pm 1.5 ; 1.4 \pm, 4$ and $3.5 \pm 1.9$ respectively. Significant reduction in pain scores occurred in patients with stage I, II and III with $p=0,000$ respectively. In patients with stage IV, the decreased of pain score was not significant $(\mathrm{p}=0.391)$. In post-chemotherapy conditions, the percentage of patients exposed to improvements in stage I, II, III and IV were $100 \%$, $96 \%, 93.9 \%$ and $75 \%$, respectively.
\end{abstract}

Keywords: Cervical cancer, stage, chemotherapy, clinical description 


\section{PENDAHULUAN}

Kanker merupakan penyakit dengan angka mortalitas yang tinggi, salah satu diantaranya adalah kanker serviks. Di negara berkembang, tingkat prevalensi kanker serviks menduduki urutan tertinggi sedangkan secara global menempati urutan kelima. Di Indonesia, jumlah penderita baru kanker serviks berkisar 90-100 kasus per 100.000 penduduk Menurut perkiraan Kementerian Kesehatan RI, di Indonesia, setiap tahun terjadi 40 ribu kasus kanker serviks (Kementerian Kesehatan RI, 2016 dan Rasjidi, 2007).

Kemoterapi pada pengobatan kanker serviks bukanlah terapi utama (Kementerian Kesehatan RI, 2016), namun efektivitas kemoterapi pada pengobatan kanker serviks berdasarkan stadium yang diderita tetap harus dievaluasi. Efektivitas kemoterapi yang merupakan terapi penunjang pada penatalaksanaan lain seperti operasi dan radiasi perlu dievaluasi karena turut menentukan tingkat keberhasilan kedua penatalaksanaan tersebut.

Tingkat keparahan kanker serviks sebagaimana halnya penyakit kanker yang lain, dinyatakan dalam stadium (Kementerian Kesehatan RI, 2016). Secara teoritis makin tinggi stadium maka makin parah kondisi kanker serviks tersebut, dengan demikian gambaran klinis yang diperoleh juga semakin buruk. Sampai saat ini, terutama di Indonesia, masih dirasakan kurangnya data klinik untuk mengevaluasi secara spesifik efektivitas kemoterapi itu sendiri pada pengobatan kanker serviks berdasarkan stadium yang diderita. Berdasarkan paparan diatas, maka yang menjadi permasalahan sehingga penelitian ini perlu dilakukan adalah bagaimana gambaran klinik penderita kanker serviks berdasarkan stadium setelah mendapakan kemoterapi selama tiga siklus. Tujuan yang ingin dicapai dalam penelitian ini adalah untuk mengetahui gambaran klinik penderita kanker serviks berdasarkan stadium setelah mendapatkan kemoterapi selama tiga siklus. Dengan demikian manfaat penelitian ini adalah untuk dapat menjadi dasar untuk mengevaluasi lebih lanjut mengenai efektivitas kemoterapi pada setiap stadium.

\section{METODE PENELITIAN}

Penelitian ini merupakan jenis penelitian non eksperimental. Data diambil secara prospektif dengan melakukan observasi lapangan untuk memperoleh data gambaran klinik. Penelitian dilakukan di RSUP Dr. Hasan Sadikin Bandung. Data yang digunakan adalah data pasien dari bulan Juni 2015 sampai dengan Maret 2016.

Populasi adalah pasien penderita kanker serviks rawat inap kelas perawatan 1, 2 dan 3 yang memenuhi kriteria inklusi. Kriteria inklusi meliputi : pasien rawat inap dengan diagnosis utama kanker serviks, pasien dengan kriteria stadium kanker yang mendapatkan pilihan terapi dengan kemoterapi baik untuk tujuan kuratif, kontrol, 
paliatif atau dalam bentuk kombinasi dengan terapi lain (stadium I sampai IV), memiliki kelengkapan data rekam medik, pertama kali menjalani kemoterapi dan menjalani absolut tiga siklus kemoterapi. Kriteria eksklusi meliputi : pasien pindahan dari rumah sakit lain, pasien waktu pulang meninggal dunia sebelum menjalani tiga siklus kemoterapi, status pasien "keluar" atas permintaan sendiri (APS). Besar sampel adalah seluruh pasien kanker serviks yang dirawat di RSUP Dr. Hasan Sadikin Bandung dari bulan Juni 2015 sampai Maret 2016 dan memenuhi kriteria inklusi.

Gambaran klinik meliputi gejala klinik dan kondisi pasca kemoterapi pada pasien kanker serviks. Gejala klinik adalah gejala yang dirasakan pasien berdasarkan hasil pemantauan dokter sebelum dan setelah menjalani kemoterapi. Gejala klinik tersebut meliputi keputihan, pendarahan vagina, sekret vagina, iritasi vagina, iritasi mukosa vulva dan nyeri (RSUP Dr. Hasan Sadikin Bandung, 2015). Gejala nyeri, berdasarkan rekam medik pasien kanker serviks di RSUP Dr. Hasan Sadikin Bandung, dinyatakan dengan skor nyeri. Skor nyeri mulai dari 0 sampai 10. Skor 0 menunjukkan pasien tidak merasakan nyeri dan peningkatan skor menunjukkan peningkatan intensitas nyeri. Data gejala klinik diperoleh dari rekam medik pasien. Kondisi pasca kemoterapi pasien adalah kondisi saat pasien akan pulang dan ditentukan oleh dokter. Terdapat tiga kriteria kondisi pasca kemoterapi berdasarkan rekam medik di RSUP Dr. Hasan Sadikin Bandung, yaitu: sembuh, mengalami perbaikan dan tidak mengalami perbaikan. Pengamatan dilakukan sampai dengan pasien menjalani tiga siklus pengobatan.

Data yang diperoleh dievaluasi secara deskriptif kecuali untuk gejala nyeri. Data pada pengamatan gejala nyeri, skor nyeri dievaluasi secara statistik dengan uji Wilcoxon dengan $\mathrm{p}<0,05$ (Suwendar dkk, 2016).

\section{HASIL DAN PEMBAHASAN}

Jumlah pasien kanker serviks yang menjalani perawatan di RSUP Dr. Hasan Sadikin Bandung dari bulan Juni 2015 sampai Maret 2016 adalah sebanyak 110 orang. Sebanyak 13 orang pasien tidak menggunakan kemoterapi dalam penatalaksanaan penyakitnya dan 97 orang pasien menjalani kemoterapi. Dari 97 orang pasien tersebut 23 orang diekslusi karena empat orang merupakan pindahan dari rumah sakit lain, delapan orang tidak selesai menjalani tiga siklus kemoterapi dan 11 orang tidak bersedia dilibatkan dalam penelitian ini. Dari delapan orang pasien yang tidak selesai menjalani tiga siklus kemoterapi tersebut, dua orang pasien berhenti menjalani terapi atas permintaan sendiri (APS), tiga orang karena tidak datang kembali untuk menjalani terapi (drop out) dan tiga orang meninggal dunia sebelum selesai menjalani tiga siklus kemoterapi. Dengan demikian jumlah pasien 
yang dilibatkan dalam penelitian ini adalah sebanyak 74 orang.

Data demografi pasien yang menjadi subyek penelitian ini dicantumkan pada Tabel 1. Sebagian besar pasien berada pada rentang usia antara 45-64 tahun dengan rata-rata usia 47,6 $\pm 8,6$ tahun. Hasil penelitian di RSUP Dr. Hasan Sadikin Bandung sebelumnya (Irvianty dan Sukarya, 2011) menunjukkan bahwa tidak ada hubungan antara usia dengan prevalensi kanker serviks. Namun demikian, terdapat pendapat lain, yaitu tingkat kejadian kanker serviks pada usia muda ternyata makin meningkat. Berdasarkan analisis retrospektif, ditemukan bahwa tingkat kejadian dan derajat keganasan kanker serviks lebih tinggi pada usia muda (Rasjidi, 2009)
Pasien yang yang menjadi subjek penelitian ini sebagian besar dengan latar belakang pendidikan di bawah SLTA $(60,8 \%)$. Tingginya kasus pada pasien dengan tingkat pendidikan rendah juga sejalan dengan hasil penelitian di RSUP Dr. Hasan Sadikin sebelumnya, yaitu tingkat kejadian pasien dengan lama pendidikan $\leq$ enam tahun mencapai $71,7 \%$ dari 46 pasien yang diteliti. Hasil penelitian tersebut menunjukkan bahwa terdapat hubungan yang bermakna antara kejadian kanker serviks dengan tingkat pendidikan pasien. Pasien dengan lama pendidikan kurang dari enam tahun lebih beresiko terkena kanker serviks (Irvianty dan Sukarya, 2011).

Tabel 1. Data Demografi Pasien Kanker Serviks yang Mendapat Kemoterapi di RSUP Dr. Hasan Sadikin Bandung (Juni 2015 Sampai Maret 2016)

\begin{tabular}{lcc}
\hline \multicolumn{1}{c}{ Demografi pasien } & n & \% \\
\hline Umur dalam tahun & \multicolumn{2}{c}{} \\
$<45$ & 21 & 28,4 \\
$45-64$ & 03 & 71,6 \\
$\geq 65$ & $47,6 \pm 8,6$ \\
Rata-rata umur (SD) & \multicolumn{2}{c}{$21-62$} \\
Kisaran Umur & \multicolumn{2}{c}{} \\
\hline Tingkat pendidikan & 28 & 37,8 \\
Lulusan SD & 17 & 23,0 \\
Lulusan SMP & 27 & 36,5 \\
Lulusan SLTA & 2 & 2,7 \\
Sarjana & \multicolumn{2}{c}{} \\
\hline Stadium & 12 & 16,2 \\
I & 33 & 44,6 \\
II & 25 & 33,8 \\
III & 4 & 5,4 \\
IV & \multicolumn{2}{|}{} \\
\hline Penatalaksanaan & 33 & 44,6 \\
kemoterapi & 41 & 55,4 \\
Kemoterapi-radiasi & \multicolumn{2}{l}{} \\
\hline
\end{tabular}


Berdasarkan tingkat keparahan penyakit yang diderita, sebagian besar pasien berada pada stadium II. Berdasarkan penelitian yang dilakukan di RSUP Dr. Hasan Sadikin pada tahun 2016, dari 32 penderita kanker serviks yang diteliti sebagian besar adalah stadium lanjut (IIB) ke atas (Wibisono dkk, 2016). Perbedaan terjadi karena dalam penelitian ini, cukup banyak pasien stadium lanjut yang tidak memenuhi kriteria inklusi atau menolak mengikuti penelitian ini.

Terdapat empat jenis penatalaksanaan pada pasien yang ditemui pada penelitian ini, yaitu: kemoterapi, kemoterapi-radiasi, kemoterapi-operasi dan kemoterapi-radiasioperasi. Hal ini sesuai dengan panduan yang diterbitkan oleh Kementerian Kesehatan (Kementerian Kesehatan Republik Indonesia, 2016). Persentase tertinggi adalah kemoterapi radiasi $(39,2 \%)$, disusul oleh kemoterapi $(28,4 \%)$, kemoterapi-operasi $(27 \%)$ dan kemoterapi-radiasi-operasi $(5,4 \%)$.

Pengelompokan di atas berdasarkan rencana terapi. Sehubungan dengan tindakan operasi baru dilaksanakan setelah siklus ketiga, maka pada penelitian ini, belum ada pasien yang menjalani operasi. Oleh karena itu, pengelompokan dibagi menjadi dua, yaitu kemoterapi dan kemoterapi-radiasi. Dari 74 orang pasien yang memenuhi syarat untuk dilibatkan dalam penelitian ini, 41 orang $(55,4 \%)$ menjalani kemoterapi dan 33 orang $(44,6 \%)$ menjalani kemoterapi-radiasi.

Berdasarkan hasil evaluasi gejala klinik berdasarkan stadium, diperoleh data persentase pasien yang tidak lagi mengalami gejala klinik setelah kemoterapi selama tiga siklus seperti yang tercantum pada Tabel 2 . Pada gejala keputihan, seluruh pasien stadium I menunjukkan hilang gejala. Untuk stadium yang lebih berat yaitu stadium II, III dan IV, persen hilang gejala masing-masing mencapai 96, 93,3 dan 25\% dari keseluruhan pasien dibandingkan saat sebelum mendapatkan kemoterapi. Pada gejala pendarahan, seluruh pasien stadium I menunjukkan hilang gejala. Untuk stadium yang lebih berat, yaitu stadium II dan III persen hilang gejala masing-masing mencapai $68 \%$ dan 53,3\%. Pada pasien stadium IV, seluruh pasien masih menderita gejala pendarahan vagina. Hasil yang agak berbeda ditunjukkan oleh penelitian di RS Sanglah Denpasar. Berdasarkan hasil penelitian tersebut, gejala keputihan dan perdarahan sudah tidak dirasakan pasien setelah mendapatkan kemoterapi tiga siklus pada semua stadium yang diamati (Tunas dkk., 2016). 
Tabel 2. Persentase Gambaran Klinis Berupa Hilang Gejala dan Kondisi Pasca Kemoterapi Berdasarkan Stadium setelah Mendapatkan Kemoterapi selama Tiga Siklus

\begin{tabular}{lcccc}
\hline \multicolumn{1}{c}{ Gambaran Klinis (\%) } & \multicolumn{4}{c}{ Stadium } \\
\cline { 2 - 5 } & $\begin{array}{c}\text { I } \\
(\mathbf{n = 1 2})\end{array}$ & $\begin{array}{c}\text { II } \\
(\mathbf{n}=\mathbf{3 3})\end{array}$ & $\begin{array}{c}\text { III } \\
(\mathbf{n = 2 5})\end{array}$ & $\begin{array}{c}\text { IV } \\
(\mathbf{n = 4})\end{array}$ \\
\hline Hilang gejala & & & & \\
1. Keputihan & 100 & 96 & 93,3 & 25 \\
2. Pendarahan vagina & 100 & 68 & 53,3 & 0 \\
3. Sekret vagina & $(-)$ & $(-)$ & $100^{*}$ & $(-)$ \\
4. Iritasi vagina & $(-)$ & $100^{*}$ & $100^{*}$ & $100^{*}$ \\
5. Iritasi mukosa vulva & $(-)$ & $(-)$ & $(-)$ & $100^{*}$ \\
\hline Kondisi pasca kemoterapi & & & & \\
1. Mengalami perbaikan & 100 & 96,0 & 93,9 & 75 \\
2. Tidak mengalami & 0 & 4,0 & 6,1 & 25 \\
$\quad$ perbaikan & & & & \\
\hline
\end{tabular}

Keterangan : (-) pasien tidak memiliki gejala tersebut pada saat sebelum kemoterapi; $(*)$ hanya terdapat satu pasien yang menderita gejala tersebut pada saat sebelum kemoterapi

Gejala berupa munculnya sekret vagina hanya diderita oleh satu orang pasien, yaitu pada stadium III, dan setelah kemoterapi tiga siklus, gejala tersebut hilang. Gejala berupa iritasi vagina, diderita oleh masing-masing satu pasien pada stadum II, III dan IV. Gejala tersebut hilang setelah kemoterapi selama tiga siklus. Gejala iritasi mukosa vulva hanya diderita oleh satu orang pasien, yaitu stadium IV. Gejala tersebut hilang setelah kemoterapi tiga siklus. Skor nyeri pasien sebelum dan setelah kemoterapi dicantumkan pada Gambar 1 dan Tabel 3. Berdasarkan data pada Gambar 1, terlihat adanya kecenderungan penurunan skor nyeri dari siklus pertama sampai siklus ketiga kemoterapi pada setiap stadium.

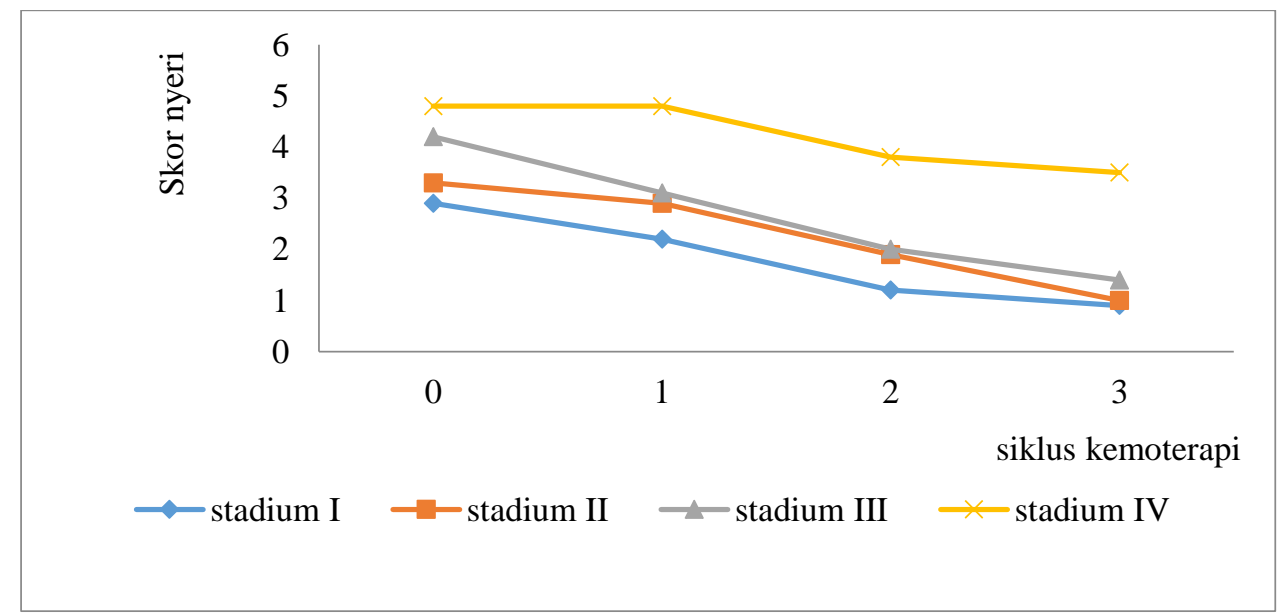

Gambar 1. Perkembangan rata-rata skor nyeri pasien setelah mendapatkan kemoterapi selama tiga siklus

Keterangan : s0=sebelum kemoterapi; $\mathrm{s} 1=$ kemoterapi siklus pertama; $\mathrm{s} 2$ : kemoterapi siklus kedua; s3=kemoterapi siklus ketiga 
Berdasarkan data Tabel 3, setelah kemoterapi selama tiga siklus, pada semua stadium, terdapat kecenderungan penurunan skor nyeri dibandingkan dengan sebelum kemoterapi. Hal ini diduga terjadi karena penggunaan obat-obat analgetika. Selain itu penurunan gejala nyeri juga dapat terjadi karena penanganan yang baik dengan upaya rehabilitasi. Hal ini sejalan dengan evaluasi gambaran klinik pada penelitian-penelitian yang dilakukan di berbagai rumah sakit di Inggris (Verhulst dkk, 2015). Berdasarkan uji statistik, penurunan skor nyeri yang bermakna terjadi pada pasien stadium I, II dan III masing-masing dengan nilai $\mathrm{p}=0,000$. Pada stadium IV, penurunan skor nyeri tidak bermakna $(\mathrm{p}=0,391)$, meskipun telah dipergunakan analgetik untuk mengatasi nyeri tersebut antara lain tramadol. Penurunan skor nyeri yang tidak bermakna ini diduga karena kondisi penyakit yang sudah berat.

Dasar yang dipergunakan untuk menyatakan perbaikan pada kondisi pasca kemoterapi adalah catatan perkembangan pasien dalam rekam medik sebelum pasien pulang. Berdasarkan Tabel 2, terdapat kecenderungan bahwa dengan makin meningkatnya stadium, maka persentase pasien yang mengalami perbaikan pada kondisi pasca kemoterapi semakin menurun. Seluruh pasien stadium I mengalami perbaikan setelah kemoterapi. Untuk stadium II dan III, persentase pasien yang mengalami perbaikan pada kondisi pasca kemoterapi, masing-masing adalah $96 \%$ dan $93,9 \%$. Persentase terendah adalah pada stadium IV, yaitu terjadi perbaikan pada $75 \%$ pasien.

Tabel 3. Skor Nyeri Pasien Kanker Serviks Sebelum dan Setelah Kemoterapi Berdasarkan Stadium

\begin{tabular}{ccccc}
\hline Stadium & $\mathbf{n}$ & \multicolumn{2}{c}{ Skor nyeri } & p \\
\cline { 3 - 4 } & & $\begin{array}{c}\text { Sebelum } \\
\text { kemoterapi }\end{array}$ & $\begin{array}{c}\text { Setelah } \\
\text { kemoterapi }\end{array}$ & \\
\hline I & 12 & $2,9 \pm 1,9$ & $0,9 \pm 0,9$ & $0,000^{*}$ \\
II & 33 & $3,3 \pm 1,4$ & $1,0 \pm 1,5$ & $0,000^{*}$ \\
III & 25 & $4,2 \pm 1,7$ & $1,4 \pm 1,4$ & $0,000^{*}$ \\
IV & 4 & $4,8 \pm 1,5$ & $3,5 \pm 1,9$ & 0,391 \\
\hline
\end{tabular}

Keterangan : $(*)$ berbeda bermakna $(\mathrm{p}<0,05)$

\section{KESIMPULAN DAN SARAN}

Berdasarkan hasil pengamatan pada pasien kanker serviks setelah mendapatkan kemoterapi selama tiga siklus, diperoleh hasil bahwa persen hilang gejala pada pasien stadium I, II, III dan IV untuk keputihan masing-masing adalah $100 \%, 96 \%, 93,3 \%$ dan $25 \%$; pada gejala pendarahan, masingmasing adalah $100 \%, 68 \%, 53,3 \%$ dan $0 \%$; rata-rata skor nyeri masing-masing adalah $0,9 \pm 0,9 ; 1,0 \pm 1,5 ; 1,4 \pm, 4$ dan $3,5 \pm 1,9$. Pada kondisi pasca kemoterapi, persentase pasien 
yang dinyatakan mengalami perbaikan pada pasien stadium I, II, III dan IV masing-masing adalah $100 \%, 96 \%, 93,9 \%$ dan $75 \%$. Hal ini menunjukkan bahwa kemoterapi menunjukkan kecenderungan makin efektif pada pasien kanker serviks dengan stadium yang makin rendah. Dengan demikian pengobatan dengan kemoterapi pada pasien kanker akan semakin efektif jika dilakukan sedini mungkin.

\section{UCAPAN TERIMA KASIH}

Ucapan terima kasih disampaikan kepada :

1. Direktur RSUP Dr. Hasan Sadikin Bandung yang telah memberikan ijin kepada peneliti untuk melakukan penelitian

2. Komite Etik Penelitian Medis dan Kesehatan Fakultas Kedokteran Universitas Gadjah Mada yang telah memberikan rekomendasi penelitian berupa ethical approval No: KE/FK/426/EC tanggal 29 April 2015.

\section{DAFTAR PUSTAKA}

Irvianty A dan Sukarya WS (2011) Hubungan Karakteristik Pasien dengan Kejadian Kanker Serviks yang Dirawat Inap di Bagian Obstetri Ginekologi Rumah Sakit Hasan Sadikin Bandung Periode 1 Januari 2010 - 31 Desember 2010, Prosiding Seminat Nasional Penelitian dan Pengabdian kepada Masyarakat 2011 Sains Teknologi dan Kesehatan, 2(1), 4754

Kementerian Kesehatan Republik Indonesia (2016) Panduan Penatalaksanaan Kanker Serviks, Komite Penanggulangan Kanker Nasional (KPKN), Jakarta, 4-5
Rasjidi I (2009) Epidemiologi Kanker Serviks, Indonesian Journal of Cancer, 3(3), 103-108

RSUP Dr. Hasan Sadikin Bandung (2015) Panduan Praktik Klinis Obstetri dan Ginekologi, Dep./ SNF Obstetri dan Ginekologi Fakultas Kdokteran Universitas Padjadjaran, Bandung, 146147

Suwendar, Fudholi A, Andayani TM dan Sastramihardja HS (2016) Evaluasi Outcome Klinik Regimen Kemoterapi Berbasis Cisplatin terhadap Pasien Kanker Serviks, Prosiding Seminar Nasional Penenlitian dan Pengabdian kepada Masyarakat 2016 Kesehatan, 2(1), 13-18

Tunas IK, Yowani SC, Indrayathi PA, Noviyani R dan Budiana ING (2016) Penilaian Kualitas Hidup Pasien Kanker Serviks dengan Kemoterapi PaklitakselKarboplatin di RSUP Sanglah, Jurnal Farmasi Klinik Indonesia, 5(1), 35-46

Verhulst ALJ, Savelberg HHCM, Vreugdenhil G, Mischi M dan Schep G (2015) Whole-Body Vibration as a Modality for Rehabilitation of Peripheral Neuropathies: Implications for Cancer Survivors Suffering from ChemotherapyInduced Peripheral Neuropathy, Oncology Reviews, 9, 263

Wibisono F, Suryanti S dan Hernowo BS (2016) Peran EGFR sebagai Prediktor Sensitivitas Radioterapi pada Adenoma Serviks, Majalah Patologi, 25(3), 28-30 
Gambaran Klinis Penderita Kanker Serviks.... 